Rev. Bras. Saúde Prod. Anim., Salvador, v.15, n.4, p.801-814 out./dez., 2014 http://www.rbspa.ufba.br ISSN 15199940

\title{
Fermentative characteristics of sugar cane silages with additives ${ }^{1}$
}

\author{
Caracterísiticas fermentativas de silagens de cana-de-açúcar com aditivos
}

\author{
ROCHA, Wéder Jânsen Barbosa ${ }^{2}$; ROCHA JÚNIOR, Vicente Ribeiro ${ }^{2 *}$; SILVA \\ Geanderson Walder Vieira da ${ }^{2}$; REIS, Sidnei Tavares dos ${ }^{2}$; RUAS, José Reinaldo \\ Mendes $^{3}$; SOARES, Camila ${ }^{2}$; MENEZES, Jordana Carvalho de ${ }^{2}$; BORGES, Lucas \\ Daniel Alcântara ${ }^{2}$
}

\footnotetext{
${ }^{1}$ Trabalho de dissertação de mestrado em zootecnia do primeiro autor.

${ }^{2}$ Universidade Estadual de Montes Claros, Departamento de Ciências Agrárias, Janaúba, Minas Gerais, Brasil.

${ }^{3}$ Empresa de Pesquisa Agropecuária de Minas Gerais, Nova Porteirinha, Minas Gerais, Brasil.

*Endereço para correspondência: vicente.rocha@unimontes.br
}

\section{SUMMARY}

This work aimed to evaluate the fermentative characteristics silages of two varieties of sugar cane with different additives. The experiment was conducted in the Department of Agricultural Sciences of UNIMONTES, Janaúba Campus - MG. A completely randomized design with a factorial scheme of 2 $\mathrm{x} 5+2$ was used, with two varieties of sugar cane (RB 867515 and IAC 86 2480) and five additives (urea, $\mathrm{NaOH}, \mathrm{CaO}$, corn and Lactobacillus buchneri), with three repetitions and one treatment without additive by variety, where the silos were opened 60 days after the ensiling. The additives $\mathrm{NaOH}$ and $\mathrm{CaO}$ promoted reductions in the losses by gases and effluents of the silages of sugar cane. The IAC 862480 variety showed better recovery rate of dry matter. The additives $\mathrm{NaOH}$ and L. buchneri reduced the water activity in the IAC 862480 variety. Corn and L. buchneri promoted lower $\mathrm{pH}$ values. The addition of urea significantly increased the amounts of ammonia nitrogen. The silages supplemented with $\mathrm{NaOH}$ and $\mathrm{CaO}$ showed high levels of lactic acid and low concentrations of ethanol. The concentration of acetic acid as a percentage of dry matter was high in all treatments. Propionic acid and butyric acid were within the ideal range for the fermentation process. The use of $\mathrm{NaOH}$ and $\mathrm{CaO}$ additives resulted in a silage with good fermentative characteristics and the best variety for the ensiling process was IAC 862480 .

Keywords: chemical additive, ethanol, fermentation, Lactobacillus buchneri, ivolatile fatty acids

\section{RESUMO}

Objetivou-se por meio deste trabalho avaliar as características fermentativas de silagens de duas variedades de cana-de-açúcar com diferentes aditivos. O experimento foi conduzido no Departamento de Ciências Agrárias da UNIMONTES, Campus de Janauba-MG. Utilizou-se um delineamento inteiramente casualizado com esquema fatorial 2 × $5+2$, sendo duas variedades de cana-de-açúcar (RB 867515 e IAC 862480 ) e cinco aditivos (ureia, $\mathrm{NaOH}, \mathrm{CaO}$, milho e Lactobacillus buchneri) com três repetições e um tratamento sem aditivo por variedade, com a abertura dos silos sendo feita aos 60 dias da ensilagem. Os aditivos $\mathrm{NaOH}$ e $\mathrm{CaO}$ propiciaram reduções nas perdas por gases e efluentes das silagens de cana-de-açúcar. A variedade IAC 862480 apresentou melhor índice de recuperação de matéria seca. Os aditivos $\mathrm{NaOH}$ e L. buchneri reduziram a atividade de água na variedade IAC 86 2480. O milho e L. buchneri propiciaram menores valores de $\mathrm{pH}$. A adição de ureia elevou significativamente os valores de nitrogênio amoniacal. As silagens aditivadas com $\mathrm{NaOH}$ e $\mathrm{CaO}$ apresentaram elevados teores de ácido lático e baixos teores de etanol. Os teores de ácido acético em porcentagem da matéria seca foram elevados em todos os tratamentos. Já o ácido propiônico e o butírico encontram-se dentro da faixa ideal, para o processo fermentativo. A utilização dos aditivos $\mathrm{NaOH}$ e $\mathrm{CaO}$ resultou em uma silagem com boas características fermentativas e a melhor variedade para o processo de ensilagem foi a IAC 862480.

Palavras-chave: aditivo químico, ácidos graxos voláteis, etanol, fermentação, Lactobacillus buchneri 


\section{INTRODUCTION}

The sugar cane emerges as a viable alternative during the dry season, presenting high productivity of green mass $\mathrm{ha}^{-1}$, low cost per ton of dry matter (DM) and maturation period coinciding with the shortage of forage (SANTOS et al., 2008) The main form of use of cane is in natura, a well established practice by producers (SIQUEIRA et al., 2007). However, such handling is difficult to feed large herds, demands considerable manual labor, and the management of sugar cane crop is hindered by both the uneven regrowth and the difficulty in cultivation plot, among other issues. The conservation of this forage via ensiling concentrates the cutting activities in a single period, favors the food handling of animals and promotes greater longevity of the sugar cane crop. However, sugar cane exhibits a high concentration of soluble carbohydrates and a rich epiphytic microflora, which leads to a major production of ethanol. This fermentative route triggers a series of chemical changes in the silage, such as loss of dry matter and effluents, affecting the nutritive value and acceptability by animals (NUSSIO \& SCHMIDT, 2005). The use of additives, depending on their characteristics in the ensiling process has as a principle the change in the main fermentative route of the process of alcoholic anaerobic fermentation and preserve the maximum nutritional value of the forage.

The use of different additives on sugarcane silage, $\mathrm{CaO}, \mathrm{NaOH}$, urea, corn and Lactobacillus buchneri, can promote improvement in the characteristics fermentative silage and therefore the use of this in animal feed, changing $\mathrm{pH}$, reducing fermentation of sucrose and ethanol gas, improving aerobic stability, minimizing total losses after opening the silo, reducing levels of NH3-N and water activity (BALIEIRO NETO et al., 2007; BALIEIRO NETO et al., 2009; BERNARDES et al., 2007; EVANGELISTA et al., 2009; KLEINSCHMIDT et al., 2006; MENDES et al., 2008; SCHMIDT et al., 2014).

Currently on the market there are numerous varieties of sugar cane. Their releases seek primarily its use in industry. It is known that the varieties suitable for the industry are also recommended as animal feed. However, it is interesting to know the chemical and fermentation of each variety for the potentiating of its use in animal nutrition. Therefore, the aim of the current research was to evaluate the fermentation characteristics of silages from two varieties of sugar cane with different additives.

\section{MATERIAL AND METHODS}

The experiment was conducted at the Department of Agricultural Sciences of the State University of Montes Claros (UNIMONTES), Janauba Campus MG.

A completely randomized design with a factorial $2 \times 5+2$ was used, with two varieties of sugar cane (RB 867515 and IAC 86 2480) and five additives (urea, $\mathrm{NaOH}, \mathrm{CaO}$, ground corn grain and Lactobacillus buchneri) with three repetitions. For each variety a control was used, i.e., silage without additive. For chopping the forage, a stationary mechanical forage harvester was used, with attempts to obtain particles with an average size of less than $2 \mathrm{~cm}$.

For each variety the following doses were used: $1 \%$ urea, $1.5 \% \mathrm{NaOH}, 2 \%$ $\mathrm{CaO}, 5 \%$ ground corn in relation to green matter. As for the inoculant, the 
strain NCIMB 40788 of the commenrcial Inoculant silo Max ${ }^{\circledR}$ was used, at a dose of $2.5 \times 10^{10}$ ufc g $^{-1}$ of forage. For preparation of the silages, cilindrical PVC silos were used, of known weights, 40 centimeters long and 10 centimeters in diameter. The bottom of the silos contained $10 \mathrm{~cm}$ of dry sand, separated from the forage by a shading screen, for quantification of the effluent produced. After complete homogenization of the forage with the additives, it was placed in the silos and compacted with the aid of a wood plunger. For each variety, approximately $3 \mathrm{~kg}$ of the chipped material was sampled as fresh forage. These samples were placed in plastic bags, identified and frozen for subsequent analysis of the original forage. After being filled, the silos were closed with PVC caps fitted with Bunsen valve, sealed with tape and then weighed. The silos were stored in the Laboratory of Food Analysis of UNIMONTES, kept at room temperature with the opening being made 60 days after ensiling. Before the opening, the silos were weighed again to determine the losses through gases. After removal of the forage, the group silo, sand, screen and tape were weighed for quantification of the effluent produced.

The gaseous losses and effluent losses were determined according to the methodology described by Schmidt (2006) and the recovery rate of dry matter (RDM) was calculated by the equation presented by Paziani et al. (2006).

When the silage from each silo was removed, the material was homogenized, where a part was pressed with the aid of a hydraulic press to extract the "juice". In the "juice" of the silage, immediately after extraction, the $\mathrm{pH}$ values were determined using a digital $\mathrm{pH}$ meter as well as the ammonia nitrogen $\left(\mathrm{NH}_{3}-\mathrm{N}\right)$ by distillation with magnesium oxide and calcium chloride, employing the receiver solution of boric acid and titration with hydrochloric acid at $0.1 \mathrm{~N}$. Ten milliliters of the "juice" were placed in containers holding $2 \mathrm{~mL}$ of metaphosphoric acid and frozen for assessment of the concentrations of organic acids (lactic, acetic, propionic and butyric acids) and ethanol by gas chromatography. A small sample of the silage was removed for determination of water activity (WA) by the method of Lutz (1985). The rest of the silage was pre-dried in a forced ventilation oven at $55^{\circ} \mathrm{C}$ to constant weight. Subsequently, the pre-dried silage was ground in a Willey-type mill, in sieves of $1 \mathrm{~mm}$, and was then analyzed for contents of MS at $105^{\circ} \mathrm{C}$ and crude protein (PB) by the Kjeldahl method (SILVA \& QUEIROZ, 2006). The total nitrogen data were used to calculate the percentage of ammonia nitrogen as a proportion of the total nitrogen (N-NH3/NT).

The chemical composition of two varieties of sugar cane in natura and ensiled without additives was determined according to the methods described by Silva \& Queiroz (2006) (Table 1).

Data were subjected to analysis of variance, and when it was significant ( $p$ $<0.05$ ), the treatment means (silages with additives) were compared by the Scott-Knott test at 5\% probability. The means of the varieties were compared by "F" test. With respect to the control (silage without additives), the means were compared by Dunnett's test at $5 \%$ probability. The analysis of variance and the Scott-Knott test were performed using the program SISVAR (FERREIRA, 2011). For application of the Dunnett test, the SAS software was used (SAS Institute, 2009). 
Rev. Bras. Saúde Prod. Anim., Salvador, v.15, n.4, p.801-814 out./dez., 2014 http://www.rbspa.ufba.br ISSN 15199940

Table 1. Chemical composition of two varieties of sugar cane in nature and ensiled without additives

\begin{tabular}{|c|c|c|c|c|}
\hline \multirow{2}{*}{ Additives } & \multicolumn{2}{|c|}{ IAC 862480} & \multicolumn{2}{|c|}{ RB 867515} \\
\hline & In natura & Silage & In natura & Silage \\
\hline Dry Matter & 26.12 & 23.55 & 28.62 & 20.94 \\
\hline Crude Protein & 1.26 & 3.15 & 3.60 & 2.73 \\
\hline Neutral Detergent Fiber & 36.79 & 50.19 & 41.32 & 60.08 \\
\hline Acid Detergent Fiber & 21.59 & 30.35 & 23.69 & 35.69 \\
\hline Hemicellulose & 17.63 & 19.85 & 15.19 & 24.39 \\
\hline Cellulose & 17.22 & 21.03 & 17.93 & 22.04 \\
\hline Lignin & 6.98 & 6.42 & 6.85 & 6.50 \\
\hline Ether Extract & 1.88 & 1.85 & 2.01 & 1.94 \\
\hline Ashes & 3.81 & 4.26 & 3.22 & 4.84 \\
\hline Non Fibrous Carbohydrates* & 51.73 & 40.64 & 54.38 & 30.50 \\
\hline
\end{tabular}

${ }^{*}$ Sniffen et al. (1992).

\section{RESULTS AND DISCUSSION}

The dry matter (DM) content of silages differed $(\mathrm{P}<0.05)$ for the different varieties and additives used. In the variety RB 86 7515, silages with $\mathrm{NaOH}$ and $\mathrm{CaO}$ showed higher $\mathrm{DM}$, followed by the silage supplemented with ground corn grain. In the variety IAC 862480 , the highest levels of DM were found in silages with $\mathrm{NaOH}, \mathrm{CaO}$ and corn. The difference between varieties for the DM content was found in silages supplemented with ground corn and in silages without additives, with the IAC 862480 showing the highest levels of DM (Table 2).

Silages with the additives $\mathrm{NaOH}, \mathrm{CaO}$ and corn had higher DM content relative to silages without additives, for the two varieties studied (Table 2).

Mean values for the content of DM of the in natura sugar canes RB 867515 and IAC 862480 were $28.62 \%$ and $26.12 \%$, respectively (Table 1). Comparing these values with those of silages supplemented with urea, $L$. buchneri and silages without additives, reveals a reduction in the DM content. Silages with the additives $\mathrm{NaOH}$ and $\mathrm{CaO}$, showed higher values for $\mathrm{DM}$, possibly by the inhibiting effect on the population of yeasts that degrade the DM of the silage. With respect to the additive corn, the explanation lies in the fact that it shows high DM content and a high level of inclusion (5\%) which contributes to elevation of this content in the silage.

The lowest values of DM in silage RB 867515 without additives relative to the IAC 862480 silage is probably due to greater activity of yeast in this silage, which can be justified by the reduction of DM seen in this variety with respect to the in natura sugarcane. The reduction of DM in the ensiled material in relation to the in natura sugarcane, can be associated with loss of DM due to the fermentation process. According to McDonald et al. (1991), ethanol production by yeast is accompanied by severe loss of DM of the substrates in the form of $\mathrm{CO}_{2}$, in addition to the loss of ethanol by volatility, thus reduction in the DM content is indicative of losses during fermentation. 
Rev. Bras. Saúde Prod. Anim., Salvador, v.15, n.4, p.801-814 out./dez., 2014 http://www.rbspa.ufba.br ISSN 15199940

Table 2. Mean values of dry matter (\% DM) and coefficient of variation (CV) of silages from two varieties of sugar cane with different additives

\begin{tabular}{lcc}
\hline \multirow{2}{*}{ Additives } & \multicolumn{2}{c}{ Varieties } \\
\cline { 2 - 3 } & $\mathrm{RB} 867515$ & $\mathrm{IAC} 862480$ \\
\hline Urea & $22.79^{\mathrm{Ac}}$ & $24.05^{\mathrm{Ab}}$ \\
$\mathrm{NaOH}$ & $28.92^{\mathrm{Aa}^{*}}$ & $28.58^{\mathrm{Aa}^{*}}$ \\
$\mathrm{CaO}$ & $28.21^{\mathrm{Aa}^{*}}$ & $27.26^{\mathrm{Aa}^{*}}$ \\
$\mathrm{Corn}$ & $25.08^{\mathrm{Bb}^{*}}$ & $28.28^{\mathrm{Aa}^{*}}$ \\
Lactobacillus buchneri & $22.09^{\mathrm{A}} \mathrm{c}$ & $22.95^{\mathrm{Ab}}$ \\
\hline Control & $20.94^{\mathrm{B}}$ & $23.55^{\mathrm{A}}$ \\
\hline CV $(\%)$ & 3.44 & \\
\hline
\end{tabular}

Means followed by different letters, uppercase in rows and lowercase in the column differ, respectively, by $\mathrm{F}$ and Scott-Knott tests at $5 \%$ probability. Means with an asterisk differ from the control treatment by Dunnett's test at $5 \%$ probability.

According to Freitas et al. (2006), addition of a product with high DM content acts as an absorbing additive, raising the DM content of the ensiled material, which makes the environment less favorable for the growth of yeasts. The chemical treatment with sodium hydroxide and calcium oxide has been used to break the lignocellulosic composite of the forage and proportionally increase its nutritional components, reducing the losses of DM (PEREIRA FILHO et al., 2003).

There was an interaction $(\mathrm{P}<0.05)$ between the variety of sugar cane with additives for gas and effluent losses. Regarding gas losses, among the varieties, there were differences in the silage with urea, corn and L. buchneri, with the variety RB 867515 showing the greatest losses. Regarding the effects of additives in each variety, it was found that in both cases, larger values for gas losses occurred for treatments with urea and Lactobacillus buchneri. The smallest losses of gases as a percentage of the initial DM were found in silages with $\mathrm{NaOH}$ and $\mathrm{CaO}$ in both varieties (Table 3 ).

In the case of $\mathrm{NaOH}$, low gas losses may be associated with inhibition of growth of bacteria present in the silo would use the sugar of the cane to develop. This hypothesis can be corroborated in Table 2, where the values of DM remained near the in natura sugarcane. Possibly $\mathrm{CaO}$ also had some effect on the population of certain micro-organisms.

Silages without additives in the IAC 86 2480 variety showed lower losses by gases relative to RB 867515 . The silages supplemented with $\mathrm{NaOH}$ and $\mathrm{CaO}$ reduced gas losses compared to silages without additives in the two varieties. In IAC $86 \quad 2480 \quad$ (silage without additive), the gas losses were even higher than the silage with corn addition.

For effluent losses, among the varieties, the silage from IAC 862480 supplemented with urea and L. buchneri had lower values than the variety RB 86 7515. However, the IAC 862480 silage, with corn addition, had greater loss compared to RB 867515 . With regards to the additives, in the same variety, it was observed that in RB 867515 the smallest effluent losses occurred for silages supplemented with $\mathrm{CaO}$ followed by silages with $\mathrm{NaOH}$ and corn. As for IAC 862480 the smallest losses only occurred with the silages supplemented with $\mathrm{CaO}$ and $\mathrm{NaOH}$. 
With respect to the silage without additives, it was found that RB 867515 exhibits higher values than those of silage supplemented with $\mathrm{CaO}$ and
$\mathrm{NaOH}$. In the silage of IAC 862480 , only the silage with corn addition did not differ from the silage without additive (Table 3 ).

Table 3. Gas losses as a percentage of the initial DM, effluent losses $\left(\mathrm{kg} \mathrm{t}^{-1}\right.$ of fresh weight) and recovery rate of dry matter (\% DM) and coefficients of variation (CV) of silages from two varieties of sugar cane with different additives

\begin{tabular}{|c|c|c|c|c|c|c|}
\hline \multirow[b]{2}{*}{ Additives } & \multicolumn{2}{|c|}{ Gas losses (\% DM) } & \multicolumn{2}{|c|}{ Effluent losses $\left(\mathrm{kg} \mathrm{t}^{-1} \mathrm{GM}\right)$} & \multicolumn{2}{|c|}{ RRDM (\% DM) } \\
\hline & RB & IAC & RB & IAC & RB & IAC \\
\hline & 867515 & 862480 & 867515 & 862480 & 867515 & 862480 \\
\hline Urea & $24.23^{\mathrm{Aa}}$ & $10.59^{\mathrm{Ba}}$ & $96.89^{\mathrm{Aa}}$ & $82.05^{\mathrm{Ba}^{*}}$ & $68.06^{\mathrm{Bc}}$ & $81.86^{\mathrm{Ab}}$ \\
\hline $\mathrm{NaOH}$ & $4.49^{\mathrm{Ac}^{*}}$ & $0.10^{\mathrm{Ab}^{*}}$ & $46.07^{\mathrm{Ac} *}$ & $47.47^{\mathrm{Ab} *}$ & $91.38^{\mathrm{Ba}^{*}}$ & $99.20^{\mathrm{Aa} *}$ \\
\hline $\mathrm{CaO}$ & $3.60^{\mathrm{Ac}^{*}}$ & $2.03^{\mathrm{Ab} *}$ & $32.39^{\mathrm{Ad}^{*}}$ & $29.06^{\mathrm{Ac} *}$ & $93.20^{\mathrm{Aa}^{*}}$ & $99.00^{\mathrm{Aa} *}$ \\
\hline Corn & $16.81^{\mathrm{Ab}}$ & $0.32^{\mathrm{Bb} *}$ & $65.53^{\mathrm{Bb}}$ & $86.34^{\mathrm{Aa}}$ & $77.43^{\mathrm{Bb} *}$ & $96.18^{\mathrm{Aa}^{*}}$ \\
\hline L.buchneri & $26.82^{\mathrm{Aa}}$ & $15.12^{\mathrm{Ba}}$ & $92.18^{\mathrm{Aa}}$ & $82.66^{\mathrm{Ba}^{*}}$ & $66.07^{\mathrm{Bc}}$ & $77.60^{\mathrm{Ab}}$ \\
\hline Control & $30.52^{\mathrm{A}}$ & $26.82^{\mathrm{B}}$ & $104.14^{\mathrm{A}}$ & $107.31^{\mathrm{A}}$ & $61.86^{\mathrm{B}}$ & $77.88^{\mathrm{A}}$ \\
\hline $\mathrm{CV}(\%)$ & & & & & & \\
\hline
\end{tabular}

Means followed by different letters, uppercase in rows and lowercase in the column differ, respectively, by $\mathrm{F}$ and Scott-Knott tests at $5 \%$ probability. Means with an asterisk differ from the control treatment by Dunnett's test at $5 \%$ probability.

$\mathrm{RRDM}=$ recovery rate of dry matter.

The IAC 862480 variety displayed the highest recovery rates of $\mathrm{DM}$, and did not differ from the variety RB 867515 $(\mathrm{P}>0.05)$ only in the treatment with calcium oxide (Table 3). These results corroborate the better preservation of nutritional constituents, especially in relation to the content of non-fiber carbohydrates in the IAC 862480 silage without additive, compared to RB 86 7515 silage (Table 1 ).

In relation to $\mathrm{NaOH}$, the low gas loss must be associated to the inhibition of growth of bacteria present in the silo that would use the sugar of the cane to develop. This fact can be confirmed in Table 2, where the values of DM remained close to those of the in natura sugar cane. Possibly the additives $\mathrm{CaO}$ and corn also had some effect on the population of certain microorganisms. The additive corn was noted to be efficient, however, this increased efficiency was observed in the IAC 86
2480 sugar cane, where the microorganism population appeared to be smaller. Results from controls of gas losses were observed by Siqueira et al. (2007) in a study evaluating the silage of raw and burned sugar cane, treated with six additives (control, $1.5 \%$ urea, $0.1 \%$ sodium benzoate, $1 \% \mathrm{NaOH}$, and Proprio lac and Laisil Cane), and documented the efficiency of $\mathrm{NaOH}$ in reducing gas losses. With regard to $\mathrm{CaO}$, Amaral et al. (2009) found that this chemical treatment was effective in reducing the production of ethanol, which is desirable, in addition to reducing gas losses.

The small loss of effluents for $\mathrm{CaO}$ can be explained by the absorbing nature of the lime, given that for the lime reaction to occur, 1 mole of $\mathrm{H}_{2} \mathrm{O}$ is required for every mole of $\mathrm{CaO}$, i.e., every 56 grams of lime required 18 grams of water (MORAES et al., 2006). 
The additives that provided the highest recovery rates of DM (Table 3 ), were $\mathrm{NaOH}$ and $\mathrm{CaO}$ in the $\mathrm{RB} 867515$ cane, and in addition, the corn additive in the variety IAC 86 2480. These treatments were effective in the recovery of DM compared to silages without additives.

The recovery rates of $\mathrm{DM}$ for the IAC 862480 cane, reinforce the hypothesis that the silages of this variety exhibited less damaging action of undesirable microorganisms. Analyzing the results presented here to the gas losses in Table 3 reveals a tendency that silages with lower gas losses have a better recovery of the initial DM, which is desirable in a process of ensiling.

Oliveira et al. (2004) found recoveries of DM of $77 \%$ for sugar cane silages plus $0.5 \%$ of hydrated lime, while in the control silage they observed a recovery of $72.1 \%$ of the DM. However, the collective analysis of the data in the literature, along with the results obtained in this study show that treatment of sugar cane silages with alkalizing agents decreases the total losses and increases the recovery of the DM.

The water activity values among the varieties did not differ $(p>0.05)$. Regarding the additives in the same variety, it was found that in the RB 86 7515 variety, corn and L. buchneri exhibited the greatest values $(\mathrm{P}<0.05)$. In the variety IAC 862480 , the additives did not differ, and only in this variety a difference was observed between silages with additives and silage without additive, with $\mathrm{NaOH}$ and L. buchneri presenting the lowest values (Table 4).

Table 4. Water activity, $\mathrm{pH}$, ammonia nitrogen in relation to the total nitrogen (NH3$\mathrm{N} / \mathrm{TN} \%$ ) and coefficients of variation (CV) of silages from two varieties of sugar cane with different additives

\begin{tabular}{|c|c|c|c|c|c|c|}
\hline \multirow{3}{*}{ Additives } & \multicolumn{2}{|c|}{ Water Activity } & \multicolumn{2}{|c|}{$\mathrm{pH}$} & \multicolumn{2}{|c|}{$\mathrm{NH}_{3}-\mathrm{N} / \mathrm{TN} \%$} \\
\hline & $\mathrm{RB}$ & IAC & $\mathrm{RB}$ & IAC & $\mathrm{RB}$ & IAC \\
\hline & 867515 & 862480 & 867515 & 862480 & 867515 & 862480 \\
\hline Urea & $0.98^{\mathrm{Ab}}$ & $0.99^{\mathrm{Aa}}$ & $3.59^{\mathrm{Ac}^{*}}$ & $3.52^{\mathrm{Ac}^{*}}$ & $2.39^{\mathrm{Aa}^{*}}$ & $1.62^{\mathrm{Ba}^{*}}$ \\
\hline $\mathrm{NaOH}$ & $0.97^{\mathrm{Ab}}$ & $0.97^{\mathrm{Aa}^{*}}$ & $4.39^{\mathrm{Ab}^{*}}$ & $4.37^{\mathrm{Ab} *}$ & $0.98^{\mathrm{Bb}}$ & $1.34^{\mathrm{Aa}}$ \\
\hline $\mathrm{CaO}$ & $0.97^{\mathrm{Ab}}$ & $0.98^{\mathrm{Aa}}$ & $4.61^{\mathrm{Aa}^{*}}$ & $4.64^{\mathrm{Aa}^{*}}$ & $0.77^{\mathrm{Ab}}$ & $0.95^{\mathrm{Ab}}$ \\
\hline Corn & $0.99^{\mathrm{Aa}}$ & $0.98^{\mathrm{Aa}}$ & $3.28^{\mathrm{Ad}}$ & $3.23^{\mathrm{Ad}}$ & $0.86^{\mathrm{Bb}}$ & $1.24^{\mathrm{Aa}}$ \\
\hline L.buchneri & $0.99^{\mathrm{Aa}}$ & $0.97^{\mathrm{Aa} *}$ & $3.24^{\mathrm{Ad}}$ & $3.25^{\mathrm{Ad}}$ & $1.08^{\mathrm{Ab}}$ & $0.94^{\mathrm{Ab}}$ \\
\hline Control & $0.98^{\mathrm{A}}$ & $0.99^{\mathrm{A}}$ & $3.29^{\mathrm{A}}$ & $3.28^{\mathrm{A}}$ & $0.65^{\mathrm{A}}$ & $0.86^{\mathrm{A}}$ \\
\hline $\mathrm{CV}(\%)$ & \multicolumn{2}{|c|}{0.72} & \multicolumn{2}{|c|}{1.57} & \multicolumn{2}{|c|}{17.02} \\
\hline
\end{tabular}

Means followed by different letters, uppercase in rows and lowercase in the column differ, respectively, by $\mathrm{F}$ and Scott-Knott tests at $5 \%$ probability. Means with an asterisk differ from the control treatment by Dunnett's test at $5 \%$ probability.

With respect to $\mathrm{pH}$ values of the silages (Table 4) the effect of additives was observed. The lowest values were found for silages supplemented with corn and L. buchneri, in both varieties analyzed. These values are similar to those silages without additives. The other treatments differed from the control at $5 \%$ probability.

There was an interaction effect of varieties with additives for the values of ammonia nitrogen $\left(\mathrm{NH}_{3}-\mathrm{N}\right)$ - (Table 4). Silages of the variety RB 867515 , with $\mathrm{NaOH}$ and corn showed lower values of 
$\mathrm{NH}_{3}-\mathrm{N}$ relative to IAC 862480 silages, and the additive urea in RB 867515 was superior to the value observed for the silage of IAC 862480 . The highest value observed between additives in $\mathrm{RB}$ 867515 occurred for silage treated with urea. In silages of the IAC 862480 variety, the highest values occurred for the additives urea, $\mathrm{NaOH}$ and ground corn. Only silage containing urea differed $(\mathrm{P}<0.05)$ from silage without additives.

In the field of ensiled food evaluation, water activity is of great importance to the quality of fermentation during ensilage and for the microbial activity during the usage phase of the silage. Microorganisms in general are fundamental in the fermentation process of silage and have their activity largely affected by the water activity. Some studies conducted in Brazil, with tropical species, show relatively high values for water activity in grass silages (JOBIM et al., 2007).

According to McDonald et al. (1991), the growth of bacteria of the genus Clostridium is inhibited with water activity below 0.94 , while the lactic acid bacteria are less sensitive. This shows that these silages may possibly have contained these bacteria.

In Brazil, there are few studies that have contemplated the evaluation of water activity in ensiled materials. Thus, the lack of information regarding water activity makes the safe conclusion of the data obtained difficult.

In the silage with urea there was transformation of this compound in ammonium hydroxide, which inhibits a decrease in the $\mathrm{pH}$. The calcium oxide, as well as calcium hydroxide, also showed higher values, certainly due to the alkaline characteristic of these additives. The high $\mathrm{pH}$ values obtained for silages treated with calcium oxide are consistent with those observed in the literature.

Ammonium nitrogen values found in this study were low; the $\mathrm{NH}_{3}-\mathrm{N} / \mathrm{TN}$ reflects the degree of protein hydrolysis and, according to Jobim \& Gonçalves (2003), the $\mathrm{NH}_{3}-\mathrm{N}$ present in the silage indicates that there was activity of clostridia, since it is produced in small amounts by lactic acid bacteria and by the activity of the enzyme deaminase of the plant. Thus, increased values show intense deamination of the amino acids from the true protein, providing a silage with poor protein quality (JOBIM et al., 2007).

In a good fermentation standard, the values of ammonia nitrogen do not exceed $12 \%$. The values found were lower than those reported by Lopes and Evangelista (2010). However, it is noteworthy that the low levels of $\mathrm{NH}_{3}$ $\mathrm{N}$ observed in this study may have been associated with low levels of CP in nature canes, which were 1.2 and $3.6 \%$ $\mathrm{CP}$, for the varieties RB 867515 and IAC 86 2480, respectively (Table 1). However, this should not be taken as the only quality parameter of silages.

The lactic acid content in both varieties were higher with $\mathrm{NaOH}$ and $\mathrm{CaO}$ additives compared to the other additives and silage without additives. Between the varieties, both were similar (Table 5).

The observed lactic acid values were high and greater to those reported by Schmidt et al. (2007) and Sousa et al. (2008), which were 0.99 and $2.33 \%$ $\mathrm{DM}$, respectively. Lactic acid can be used as a substrate by yeast. This group of microorganisms are the main microorganisms responsible for the production of ethanol in sugar cane silages. The production of lactic acid promotes a faster acidification and lower final $\mathrm{pH}$, in addition to the reduction in the rate of protein 
degradation of silages (WEINBERG \& MUCK, 1996). Given that yeasts can survive in $\mathrm{pH}$ near or below 2 (McDONALD et al. 1,991), high lactic acid content would tended to increase the production of ethanol. However, this was not observed in these silages. For exactly where the lactic acid values were higher, the lower production of this alcohol was observed.

Table 5. Lactic acid and ethanol (\% DM) and coefficients of variation (CV) of silages from two varieties of sugar cane with different additives

\begin{tabular}{lcccc}
\hline \multirow{2}{*}{ Additives } & \multicolumn{2}{c}{ Lactic Acid (\% DM) } & \multicolumn{2}{c}{ Ethanol (\% DM) } \\
\cline { 2 - 5 } & $\mathrm{RB} 867515$ & IAC 86 2480 & RB 86 7515 & IAC 86 2480 \\
\hline Urea & $9.40^{\mathrm{Ab}^{*}}$ & $5.56^{\mathrm{Bb}}$ & $35.25^{\mathrm{Aa}}$ & $15.60^{\mathrm{Ba}^{*}}$ \\
$\mathrm{NaOH}$ & $12.58^{\mathrm{Aa}^{*}}$ & $12.09^{\mathrm{Aa}^{*}}$ & $2.24^{\mathrm{Ac}^{*}}$ & $0.49^{\mathrm{Ab}^{*}}$ \\
$\mathrm{CaO}$ & $14.04^{\mathrm{Aa}^{*}}$ & $14.46^{\mathrm{Aa}^{*}}$ & $1.89^{\mathrm{Ac}^{*}}$ & $3.92^{\mathrm{Ab}^{*}}$ \\
$\mathrm{Corn}$ & $3.82^{\mathrm{Ac}}$ & $5.30^{\mathrm{Ab}}$ & $24.28^{\mathrm{Ab}^{*}}$ & $8.63^{\mathrm{Bb} *}$ \\
L.buchneri & $5.37^{\mathrm{Bc}}$ & $8.00^{\mathrm{Ab}}$ & $42.93^{\mathrm{Aa}^{*}}$ & $20.62^{\mathrm{Ba} *}$ \\
\hline Controle & $5.45^{\mathrm{A}}$ & $6.05^{\mathrm{A}}$ & $36.17^{\mathrm{A}}$ & $26.52^{\mathrm{B}}$ \\
\hline $\mathrm{CV}(\%)$ & & & \multicolumn{2}{c}{30.32}
\end{tabular}

Means followed by different letters, uppercase in rows and lowercase in the column differ, respectively, by $\mathrm{F}$ and Scott-Knott tests at $5 \%$ probability. Means with an asterisk differ from the control treatment by Dunnett's test at $5 \%$ probability.

Silva et al. (2014) evaluated the in situ degradability of silages of the same varieties of sugar cane and additives studied in this experiment, found higher soluble fraction of dry matter silages with $\mathrm{NaOH}$ and $\mathrm{CaO}$, which can be explained by the fact that alkalizing substances having the capacity to solubilize part of the fiber. Therefore, the increased level of lactic acid in silages with these additives may be related to an increased availability of soluble carbohydrates for fermentation. According to Amaral et al. (2009), the alkalis act in lignin carbohydrates complex altering the structure of the polysaccharides, cellulose expanding, breaking intermolecular bonds and solubilizing part of the hemicellulose.

Regarding the concentration of ethanol, in the two varieties the lowest values were for $\mathrm{NaOH}$ and $\mathrm{CaO}$ additives. The use of the inoculant, because it is a heterofermentative microorganism, may be beneficial in two ways: by inhibiting yeast growth and, consequently, causing the production of ethanol to be lower, and also by the increase in aerobic stability of the silages (ÁVILA et al., 2008). The results of the literature regarding these benefits are controversial and there are several mechanisms that can influence the action of L.buchneri in the process of the conservation of the silage, including the dosage of the inoculant and the viability of the microorganism. In this research this additive was effective only in relation to the control silage in the variety IAC 862480 .

In general, the silages from variety IAC 862480 showed the best results, presenting lower production of ethanol, a fermentative route that represents a loss of about $49 \%$ of DM of the substrates. This loss is mainly composed of soluble carbohydrates, although the energy loss is minimized by the high energetic concentration in ethanol (McDONALD et al., 1991). As can be seen in table 1, the silage without additive from variety IAC 862480 
preserved highest concentration of nonfiber carbohydrates, which in sugar cane, are mainly composed of soluble carbohydrates.

Pedroso et al. (2007) using the dosages of $1,2,3 \%$ of $\mathrm{NaOH}$ in the green mass of the sugar cane, verified a reduction in the content of ethanol of $3.06 \%$ in the control silage for $2.4 \%$ of the DM, in the means of the silages treated with this product.

Sousa et al. (2008) observed a reduction of 4.78 to $0.37 \%$ ethanol as a percentage of the DM of control silage and those supplemented with calcium oxide at a dose of $1.5 \%$ of green matter, respectively. These data confirm the effect of these alkaline agents in silages of sugar cane. These agents are directly related to the hydrolysis of the cell wall components, but also act over the development of undesirable microorganisms.

The silage from the IAC 862480 variety with the microbial additive showed the largest amount of acetic acid, and differed from the RB 867515 , from the other additives, and also the silage without additive $(\mathrm{p}<0.05)$. Within the same variety, the silages with $\mathrm{NaOH}$, in the variety RB 867515 and L. buchneri in the IAC 862480 were higher than the other additives. The values were relatively high, except in the silage of the variety RB 867515 , supplemented with corn, which was $1.97 \%$ of the DM.

Table 6. Volatile fatty acid (\% DM) and coefficients of variation (CV) of silages from two varieties of sugar cane with different additives

\begin{tabular}{lcccccc}
\hline \multirow{2}{*}{ Additives } & \multicolumn{2}{c}{ Acetic Acid (\% DM) } & \multicolumn{2}{c}{ Propionic Acid (\% DM) } & \multicolumn{2}{c}{ Butyric Acid (\% DM) } \\
\cline { 2 - 7 } & RB & IAC & RB & IAC & RB & IAC \\
& 867515 & 862480 & 867515 & 862480 & 867515 & 862480 \\
\hline Urea & $3.22^{\mathrm{Ab}^{*}}$ & $2.68^{\mathrm{Ac}^{*}}$ & $0.42^{\mathrm{Ab}}$ & $0.43^{\mathrm{Ab}}$ & $0.016^{\mathrm{Ab}}$ & $0.004^{\mathrm{Bb}}$ \\
$\mathrm{NaOH}$ & $5.30^{\mathrm{Aa}}$ & $2.74^{\mathrm{Bc}}$ & $0.10^{\mathrm{Ac}}$ & $0.12^{\mathrm{Ac}}$ & $0.003^{\mathrm{Ac}}$ & $0.004^{\mathrm{Ab}}$ \\
$\mathrm{CaO}$ & $3.56^{\mathrm{Ab} *}$ & $4.10^{\mathrm{Ab}}$ & $0.77^{\mathrm{Aa}}$ & $0.70^{\mathrm{Aa}}$ & $0.106^{\mathrm{Aa}}$ & $0.082^{\mathrm{Ba}^{*}}$ \\
$\mathrm{Corn}$ & $1.97^{\mathrm{Ac}}$ & $2.55^{\mathrm{Ac}}$ & $0.18^{\mathrm{Ac}}$ & $0.08^{\mathrm{Ac}}$ & $0.001^{\mathrm{Ac}}$ & $0.002^{\mathrm{Ab}}$ \\
L.buchneri & $2.50^{\mathrm{Bc} *}$ & $5.17^{\mathrm{Aa}}$ & $0.33^{\mathrm{Ab}}$ & $0.24^{\mathrm{Ac}}$ & $0.003^{\mathrm{Ac}}$ & $0.007^{\mathrm{Ab}}$ \\
\hline Control & $5.41^{\mathrm{A}}$ & $3.98^{\mathrm{B}}$ & $0.27^{\mathrm{A}}$ & $0.19^{\mathrm{A}}$ & $0.004^{\mathrm{A}}$ & $0.005^{\mathrm{A}}$ \\
\hline CV $(\%)$ & \multicolumn{7}{c}{36.91} & \multicolumn{3}{c}{27.11} \\
\hline
\end{tabular}

Means followed by different letters, uppercase in rows and lowercase in the column differ, respectively, by $\mathrm{F}$ and Scott-Knott tests at $5 \%$ probability. Means with an asterisk differ from the control treatment by Dunnett's test at $5 \%$ probability.

According to McDonald et al. (1991), the presence of acetic acid is undesirable and levels above $2 \%$ of the DM may show the action of enterobacteria and reduce consumption by animals. Regarding the control silage and those supplemented with urea, the values observed here were higher than 1.87 and $2.27 \%$ DM found by Castro Neto et al. (2008), respectively. For the values of propionic acid, there was only an effect of additives, where the quicklime in both varieties was higher than the other treatments. The values ranged from 0.08 to $0.77 \%$ of the DM and are within the desirable range, which is from 0 to $1 \%$, and can be classified as good quality, as cited by Mahanna (1993).

The content of butyric acid (Table 5) showed differences, and the highest values observed within each variety 
Rev. Bras. Saúde Prod. Anim., Salvador, v.15, n.4, p.801-814 out./dez., 2014 http://www.rbspa.ufba.br ISSN 15199940

were for silage with $\mathrm{CaO}$, being superior to other additives and control silages. The quicklime was not effective in controlling this type of fermentation. Among the varieties, for this same additive, the content of butyric acid was greater in the variety RB 867515. Possibly, there was a greater attack on undesirable microorganisms in this variety, since gas losses (Table 3 ) were also greater for RB 86 7515. This may have contributed to greater butyric fermentation in relation to the IAC 86 2480 variety.

The butyric acid reflects the extent of the clostridial activity and values between 0 and $0.3 \%$ indicate good fermentation and lower energy losses and dry matter (TOMICH et al., 2003).

The additives $\mathrm{NaOH}$ and $\mathrm{CaO}$ allow better fermentation quality of sugar cane silages and the best variety for the ensiling process was IAC 862480. These results are in agreement to those reported by Silva et al. (2014), that when assessing the silages of the same varieties of sugarcane and additives tested in this experiment concluded that, the silages treated with $\mathrm{NaOH}$ and $\mathrm{CaO}$ are the best in nutritional value, because of the highest effective degradability of dry matter and neutral detergent fiber and the IAC 86-2480 variety presents better nutritional value than RB 867515 , due to the highest effective degradability of dry matter.

\section{ACKNOWLEDGEMENTS}

To FAPEMIG for financial support and to CNPq and CAPES for support with scholarships.

\section{REFERENCES}

AMARAL, R.C.; PIRES, A.V.; SUSIN, I.; NUSSIO, L.G.; FERREIRA, E.M.; GENTIL, R.S. Cana-de-açúcar in natura ou ensilada com e sem aditivos químicos: estabilidade aeróbia dos volumosos e das rações. Revista Brasileira de Zootecnia, v.38, n.10, p.1857-1864, 2009.

ÁVILA, C.L.S.; PINTO, J.C.; SUGAWARA, M.S.; SILVA, M.S.; SCHWAN, R.F. Qualidade da silagem de cana-de-açúcar inoculada com uma cepa de Lactobacillus buchneri. Acta Scientiarum Animal Sciences, v.30, n.3, p.255-261, 2008.

BALIEIRO NETO, G.; SIQUEIRA, G.R.; REIS, R.A.; NOGUEIRA, J.R.; ROTH, M.T.P.; ROTH, A.P.T.P. Óxido de cálcio como aditivo na ensilagem de cana-de-açúcar. Revista Brasileira de Zootecnia, v.36, n.5, p.1231-1239, 2007.

BALIEIRO NETO, G.; FERRARI JÚNIOR, E.; NOGUEIRA, J.R.; POSSENTI, R.; BUENO, M.S. Perdas fermentativas, composição química, estabilidade aeróbia e digestibilidade aparente de silagem de cana-de-açúcar com aditivos químicos e microbianos.

Pesquisa Agropecuária Brasileira, v.44, n.6, p.621-630, 2009.

BERNARDES, T. F.; REIS, R.A.; SIQUEIRA, G.R.; BERCHIELLI, T.T.; COAN, R.M. Avaliação da queima e da adição de milho desintegrado com palha e sabugo na ensilagem de cana-deaçúcar. Revista Brasileira de Zootecnia, v.36, p.269-275, 2007. 
Rev. Bras. Saúde Prod. Anim., Salvador, v.15, n.4, p.801-814 out./dez., 2014 http://www.rbspa.ufba.br ISSN 15199940

CASTRO NETO, A.G.; MOLINA, L.R.; GONÇALVES, L.C.; JAYME, C.G.

Parâmetros de fermentação de silagens de cana-de-açúcar submetidas a diferentes tratamentos. Arquivo Brasileiro de Medicina Veterinária e Zootecnia, v.60, n.5, p.1150-1156, 2008.

EVANGELISTA, A. R.; SIQUEIRA, G.R.; LIMA, J.A.; LOPES, J.;

REZENDE, A.V. Alterações

bromatológicas e fermentativas durante $\mathrm{o}$ armazenamento de silagens de cana-deaçúcar com e sem milho desintegrado com palha e sabugo. Revista Brasileira de Zootecnia, v.38, n.1, p.20-26, 2009.

FERREIRA, D.F. SISVAR: A computerstatisticalanalysis system. Ciência e Agrotecnologia, v.35, n.6, p.1039-1042, 2011.

FREITAS, A.W.P.; PEREIRA, J.C.; ROCHA, F.C.; COSTA, M.G.; LEONEL, F.P.; RIBEIRO, M.D. Avaliação da qualidade nutricional da silagem de cana-de-açúcar com aditivos microbianos e enriquecida com resíduo da colheita de soja. Revista Brasileira de Zootecnia, v.35, n.1, p.38-47, 2006.

INSTITUTO ADOLFO LUTZ. Normas analíticas do instituto Adolfo Lutz: métodos químicos e físicos para analise de alimentos. 3.ed. São Paulo: Adolfo Lutz, v.1, 332p. 1985.

JOBIM, C.C.; GOLÇALVES, G.D. Microbiologia de forragem conservada. Volumosos na produção de ruminantes: valor alimentício de forragens. Jaboticabal: Funep, 2003. $264 p$.

JOBIM, C.C.; NUSSIO, L.G.; REIS, R.A. Avanços metodológicos na avaliação da qualidade da forragem conservada. Revista Brasileira de Zootecnia, v.36, p.101-119, 2007. Supl. especial.
KLEINSCHMIDT, D. H.; KUNG JUNIOR, L. A meta-analysis of the effects of lactobacillus buchneri on the fermentation and aerobic stability of corn and grass and small-grain silages.

Journal of Dairy Science, v.89, n.10, p.4005-4013, 2006.

LOPES, J.; EVANGELISTA, A.R. Características bromatológicas, fermentativas e população de leveduras de silagens de cana-de-açúcar acrescidas de ureia e aditivos absorventes de umidade. Revista Brasileira de Zootecnia, v.39, n.5, p.984-991, 2010.

MAHANNA, B. Troubleshooting silage problems. In: STATE APPLIED NUTRITION CONFERENCE, 4, 1993, Wisconsin. Proceedings... Wisconsin, 1993. p.1-21.

McDONALD, P.; HENDERSON, A.R.; HERON, S. J.E. The biochemistry of silage. 2.ed. Marlow: Chalcombe Publications, 1991. 340p.

MENDES, C.Q.; SUSIN, I.; NUSSIO, L.G.; PIRES, A.V.; RODRIGUES, G.H.; URANO, F.S. Efeito do Lactobacillus buchneri na fermentação, estabilidade aeróbia e no valor nutritivo de silagem de cana-de-açúcar. Revista Brasileira de Zootecnia, v.37, p.2191-2198, 2008.

MORAES, K.A.K.; VALADARES FILHO, S. C.; MORAES, E.H.K.; LEÃO, M.I.; VALADARES, R.F.D.; DETMANN, E.; BRITO, A.F.; NALON, P.M. SOLERO, B.P.; Cana-de-açúcar tratada com óxido de cálcio fornecida com diferentes níveis de concentrado para novilhas de corte em confinamento.

Revista Brasileira de Zootecnia, v.37, n.7, p.1293-1300, 2008. 
Rev. Bras. Saúde Prod. Anim., Salvador, v.15, n.4, p.801-814 out./dez., 2014 http://www.rbspa.ufba.br ISSN 15199940

NUSSIO, L.G.; SCHMIDT. Silagens de cana-de-açúcar para bovinos leiteiros: aspectos agronômicos e nutricionais. In: VISÃO TÉCNICA E ECONÔMICA DA PRODUÇÃO LEITEIRA, 2005, Piracicaba. Anais... Piracicaba: Fundação de Estudos Agrários Luiz de Queiroz, 2005. p.193-218.

OLIVEIRA, M. W.; MENDES L.C.; MARQUES W.P. Adição de hidróxido de cálcio à silagem de cana. In:

CONGRESSO NACIONAL DE ZOOTECNIA, 9, 2004, Brasília. Anais... Brasília: ZOOTEC, 2004.

PAZIANI, S.F.; NUSSIO, L.G.; LOURES, D.R.S.; IGARASI, M.S.; PEDROSO, A.F.; MARI, L.J. Influência do teor de matéria seca e do inoculante bacteriano nas características físicas e químicas da silagem de capim Tanzânia. Acta Scientiarum. Animal Sciences, v.28, n.3, p.265 -271, 2006.

PEDROSO, A.F.; NUSSIO, L.G.; LOURES, D.R.S.; PAZIANI, S.F.; IGARASSI, M.S.; COELHO, R.M.; HORII, J.; RODRIGUES, A.A. Efeito do tratamento com aditivos químicos e inoculantes bacterianos nas perdas e na qualidade de silagens de cana-de-açúcar. Revista Brasileira de Zootecnia, v.36, n.3, p.558-564, 2007.

PEREIRA FILHO, J.M.; VIEIRA, E.L.; SILVA, A.M.A.; CEZAR, M.F.; AMORIM, F.U. Efeito do Tratamento com Hidróxido de Sódio sobre a Fração Fibrosa, Digestibilidade e Tanino do Feno de Jurema-Preta (Mimosa tenuiflora. Wild). Revista Brasileira de Zootecnia, v.32, n.1, p.70-76, 2003.

SANTOS, M.C.; NUSSIO, L.G.; MOURÃO, G.B.; SCHMIDT, P.; MARI, L.J.; RIBEIRO, J.L. Influência da utilização de aditivos químicos no perfil da fermentação, no valor nutritivo e nas perdas de silagens de cana-de-açúcar.
Revista Brasileira de Zootecnia, v.37, n.9, p.1555-1563, 2008.

SAS Institute. User's guide: statistics. Version 9.2. Cary, 2009.

SCHMIDT, P. Perdas fermentativas na ensilagem, parâmetros digestivos $e$ desempenho de bovinos de corte alimentados com rações contendo silagens de cana-de-açúcar. 2006. 228f. Tese (Doutorado em Ciência Animal e Pastagens) - Escola Superior de Agricultura "Luiz de Queiroz", Universidade de São Paulo, Piracicaba.

SCHMIDT, P.; MARI, L.J.; NUSSIO, L.G.; PEDROSO, A.F.; PAZIANI, S.F.; WECHSLER, F. S. Aditivos químicos e biológicos na ensilagem de cana-deaçúcar. 1. Composição química das silagens, ingestão, digestibilidade e comportamento ingestivo. Revista Brasileira de Zootecnia, v.36, n.5, p.1666-1675, 2007. Supl.

SCHMIDT, P.; NUSSIO, L. G.; QUEIROZ, O.C.M.; SANTOS, M.C.; ZOPOLLATTO, M.; TOLEDO FILHO, S.G.; DANIEL, J.L.P. Effects of Lactobacillus buchneri on the nutritive value of sugarcane silage for finishing beef bulls. Revista Brasileira de Zootecnia, v.43, p.8-13, 2014.

SILVA, D.J.; QUEIROZ, A.C. Análise de alimentos: métodos químicos e biológicos. 3.ed. Viçosa, MG: Universidade Federal de Viçosa, 2006. $235 p$.

SILVA, G.W.V.; ROCHA JÚNIOR, V.R.; ROCHA, W.J.B.; REIS, S.T.; PIRES, D.A.A.; ANTUNES, A.P.S.; ALMEIDA FILHO, S.H.C.; OLIVEIRA, L.M.; CALDEIRA, L.A.; SOUZA, V.M. Degradabilidade in situ das silagens de variedades de cana-de-açúcar com aditivos. Archivos de Zootecnia, v.63, n.241, p.171-182, 2014. 
SNIFFEN, C.J.; CONNOR, J.D.; VAN SOEST, P.J.; FOX, D.G.; RUSSELL, J.B. A net carbohydrate and protein system for evaluating cattle diets: II. Carbohydrate and protein availability. Journal of Dairy Science, v.70, n.11, p.3562-3577, 1992.

SIQUEIRA, G.R.; REIS, R.A.; SCHOCKEN-ITURRINO, R.P.; BERNARDES, T.F.; PIRES, A.J.V.; ROTH, M.T.P.; ROTH, A.P.T.P. Associação entre aditivos químicos e bacterianos na ensilagem de cana-deaçúcar. Revista Brasileira de Zootecnia, v.36, n.4, p.789-798, 2007.

SOUSA, D.P.; MATTOS, W.R.S.;

NUSSIO, L.G.; MARI, L.J.; RIBEIRO, J.L.; SANTOS, M.C. Efeito de aditivo químico e inoculantes microbianos na fermentação e no controle da produção de álcool em silagens de cana-deaçúcar. Revista Brasileira de Zootecnia, v.37, n.9, p.1564-1572, 2008.
TOMICH, T.R.; PEREIRA, L.G.R.; GONÇALVES, L.C. Características químicas para avaliação do processo fermentativo de silagens: uma proposta para qualificação da fermentação. Corumbá: Embrapa Pantanal, 2003. 20p. (Série Documentos).

WEINBERG, Z.G.; MUCK, R.E. New trends and opportunities in the development and use ofoculants for silage. FEMS Microbiology Reviews, v.19, p.53-68, 1996.

Data de recebimento: 18/11/2013

Data de aprovação: 29/10/2014 